\title{
The Effect of Husbandry and Management System on Sudan Desert Sheep Leather Production and Quality
}

\section{Ebrahiem MA* \\ Department of Animal Production, University of Kordofan, Sudan}

*Corresponding author: Mohammed Alhadi Ebrahiem, Faculty of Natural Resources and Environmental Studies, University of Kordofan, Sudan, Email: mahaali5656@gmail.com

\section{Research Article \\ Volume 4 Issue 2}

Received Date: February 12, 2019

Published Date: May 14, 2019

DOI: 10.23880 /oajvsr-16000175

\section{Abstract}

This trail is aimed to demonstrate the effect of husbandry and management system on Sudan desert sheep performance and skin quality. For this purpose a questionnaire was designed and distributed randomly for 20 sheep breeders in each of the five chosen sheep breed area's (Total of 100 ques.). The questionnaire include beside the personal data, twenty two (22) questions mainly about; system of feeding and application methods in each season, husbandry systems in each season, the main effective treatments on skins quality and common skin diseases and external parasites. The results revealed that, most of Sudan desert sheep owners or breeders were illiterate and most of them were herder $48.0 \%$, while $37.5 \%$ were herder and farmer at the same time. All respondents confirmed that the open system depending on natural grazing was the main husbandry and management system in all study target area. In autumn sheep depends totally on natural pasture grazing, while in winter sheep partly fed on natural grazing and the breeders complete it's feeding depending on the litter that remained from food crops after harvesting. Sudan desert sheep breeder in summer are using their stock of forage hay that collected either during the rainy season from good growing autumn pastures or from agricultural byproducts such as sorghum and sesame straw or groundnut residuals. The additional diets is varies by the variation of Sudan desert sheep locations. sometimes when forage are limited and for marketing purposes Sudan desert sheep breeders adding little amount or uncountable amount of sorghum grains, cotton seed cakes, groundnut seed cake as finisher diet concentrate beside agricultural byproducts such as groundnut byproduct hay, sorghum byproduct hay and sesame byproduct hay for the herd that offered for sale or for fleshing or steaming up ewes during lambing season. Branding is the most common and known damage in skins generally. Also some animal breeder's belief that by means of hot iron branding some animals may acquire immunity against certain diseases. The respondents attributed causes of mechanical damages of skins of animals on range land mainly to the domination of thorny bushes and grass with hairy and spiny seeds in pastures. External parasites and skin diseases cause most of skins damages and wastages in Sudan generally. Sheep pox spreads on sheep skins with high rates (88\%). On the other hand, mange are resulting in (8\%) of 


\section{Open Access Journal of Veterinary Science \& Research}

sheep skins infections. However, ticks infect most of sheep skins (80\%), when Lice infection estimated at 20\% of sheep skins.

Keywords: Husbandry; Management System; Sudan Desert Sheep; Leather Production

\section{Introduction}

The livestock sector in Sudan represents as the second pillar of the Sudanese economy after petroleum and contributes with about more than a fifth of Sudan's GDP and more than $25 \%$ of Sudan's total export earnings of non-petroleum products. Livestock generally cover domestic consumption of red meat, which is estimated at half a million tons a year, worth about 700 million Dollars, also livestock contributes in securing domestic consumption of dairy and providing row material for Leather Industries [1].

The estimated number of Sudan livestock was growing up from 59,764 thousand head in 1990 - 1991 to 140,909 thousand head in 2009 with total growth rate $135.8 \%$; at a rate of $149 \%$ for sheep $97.7 \%$ for cattle and $183.2 \%$ for goats and $63.9 \%$ for camel [2]. Livestock plays a major role in food security as providing the country's need of red meat and dairy and poultry products and fish along with growing surpluses for export of live animal, meat, leather and fishes.

The livestock sector in Sudan contributes annually with beef and leather exports returns and also considered as country revenue from taxes and fees and zakat. The livestock sector is a source of subsistence and income for about $80 \%$ of the rural population [1].

Sudan desert sheep are vital to subsistence and economic development in Sudan. They provide a flow of essential food products throughout the year, are a major source of government revenue and export earnings, sustain the employment and income of millions of people in rural areas, contribute draught energy and manure for crop production and are the only food and cash security available to many Sudanese .The Sudan Desert sheep is one of the leading mutton and milk-producing types in the tropics but its importance is little known due to lack of publicity. They comprise more than 60 percent of the sheep population of the Sudan and almost 100 percent of its sheep exports. Sudan desert sheep together with their cross progeny are supplying approximately 90-95 percent of the slaughter sheep in the northern regions of the country [3]. So this trail is aimed to demonstrate the effect of husbandry and management system on Sudan desert sheep performance and skin quality.

\section{Materials and Methods}

\section{The Study Area}

Sudan desert sheep home lands in the Sudan are identified north of latitude $12^{\circ} \mathrm{N}$. This study was carried out at Kordofan in the western part of Sudan, Gazira and Buttana in the middle and eastern parts of Sudan, where the most important Sudan desert sheep population is dominating.

\section{Kordofan Region}

Kordofan region is located between latitudes $9 \circ: 30$ and 16 : 30 - North and longitudes $24^{\circ}$ and $32^{\circ}$ : 25 - East. The region consists of North and South states forming a total area of $380,000 \mathrm{Km}^{2}$ ( 90 million fedan). Each of the two states existed independently of one another, while subscripting authority and jurisdiction of the federal government [4].

\section{Gazira and Butana Region}

Gazira state lies between the Blue Nile and the White Nile in the east-central region of the country (latitudes $14^{\circ}: 30-$ and $33^{\circ}: 30$ - North and longitudes $14^{\circ}: 50$-and $33^{\circ}$ : 50 - East). It has an area of $27,549 \mathrm{~km}^{2}$. The name comes from the Arabic word for island. Wad Madani is the capital of the [5].

Butana plain is a semiarid clay region, covers part of Gazera and most of the present Kassala and Gedaref States in Eastern Sudan. It lies between Latitude $13^{\circ}: 40$ and $17^{\circ}: 50$-North and Longitude $32^{\circ}: 40$ - and $36^{\circ}$ East. It is bound by the Main River Nile on its northwestern border, the Blue Nile on its southwestern edge, the Atbara River in the northeast and by the railway connecting Kassala and Sennar in the south [6].

\section{Data Collection}

A questionnaire was designed and distributed randomly for 20 sheep breeders in each of the five chosen sheep breed area's (Total of 100 ques.). The chosen sheep 
breeds were; Shugor, Dubasi and Watish from Gazira and Butana region, while Kabashi and Hamari from Kordofan region. The questionnaire include beside the personal data, twenty two (22) questions mainly about; system of feeding and application methods in each season, husbandry systems in each season, the main effective treatments on skins quality and common skin diseases and external parasites.

\section{Statistical Analysis}

Questionnaire data was analyzed using frequencies and percentages.

\section{Results and Discussion}

Some demographic characteristics of the respondents selected for the purpose of data collection for the study on the effect of husbandry and management system on Sudan desert sheep performance and skin quality is shown in Table 1.

\begin{tabular}{|c|c|}
\hline Breeders of & \% \\
\hline Hamary & 20 \\
\hline Kabashi & 20 \\
\hline Butana & 20 \\
\hline Dubasi & 20 \\
\hline Watich & 20 \\
\hline Sex & 95 \\
\hline Male & 5 \\
\hline \multicolumn{2}{|c|}{ Educationale } \\
\hline illiterate & 40 \\
\hline Quranic & 6.5 \\
\hline Primary & 43 \\
\hline Secondary & 7.5 \\
\hline University & 3 \\
\hline \multicolumn{2}{|c|}{ Main occupations } \\
\hline Herder & 48 \\
\hline Farmer & 1.5 \\
\hline Herder and farmer & 37.5 \\
\hline Employee & 3.5 \\
\hline Merchant & 3 \\
\hline Student & 6.5 \\
\hline \multicolumn{2}{|c|}{ Marital status } \\
\hline Married & 71 \\
\hline Single & 26 \\
\hline Widowed & 2 \\
\hline Not specific & 1 \\
\hline Somer & \\
\hline
\end{tabular}

Table 1: Some Demography Characteristics of the Sudan desert sheep breeders.
The results have indicated that $95 \%$ of sheep breeders were male and $5 \%$ were female. The educational data have indicated that $40 \%$ of the respondents were illiterate while $43 \%$ were primary school leavers, $7.5 \%$ completed secondary school, $6.5 \%$ were attendants of Quranic schools and only 3\%were university graduates. The data revealed that most of Sudan desert sheep owners or breeders were illiterate and that was a factor which affected their speed to accept the new changes, especially in their traditional husbandry systems.

Most of the respondents were herder $48.0 \%$, while $37.5 \%$ were herder and farmer at the same time. A farmer represented $1.5 \%$ and students amounting to $6.5 \%$. There were $3.5 \%$ of the respondents from Government employees and $3 \%$ were merchants.

All respondents confirmed that the open system depending on natural grazing was the main husbandry and management system in all study target area. Also it's suitable for rearing Sudan desert sheep for its benefits and cheapest as a feeding system. This confirms EL Hag, et al. [3] who stated that, in spite of the importance of sheep they are still raised under nomadic condition with traditional methods of management and national grazing. Many socio-economic factors affected mobility of nomadic flocks including national pasture. Also, it confirms with which Mufarrih [7] reported, the vast-majority of Sudan Desert sheep exist under migratory range conditions while a few small flocks exist under a semi-residential system. The pattern of management adopted in the whole region is essentially the same.

In autumn sheep depends totally on natural pasture grazing, while in winter sheep partly fed on natural grazing and the breeders complete it's feeding depending on the litter that remained from food crops after harvesting. Sudan desert sheep breeder in summer are using their stock of forage hay that collected either during the rainy season from good growing autumn pastures or from agricultural byproducts such as sorghum and sesame straw or groundnut residuals. The additional diets is varies by the variation of Sudan desert sheep locations. sometimes when forage are limited and for marketing purposes Sudan desert sheep breeders adding little amount or uncountable amount of sorghum grains, cotton seed cakes, groundnut seed cake as finisher diet concentrate beside agricultural byproducts such as groundnut byproduct hay, sorghum byproduct hay and sesame byproduct hay for the herd that offered for sale or for fleshing or steaming up ewes during lambing season (Table 2). This is confirming with what was EL Hag, et al. [7] mentioned; during the grazing season, sheep are able 
to meet their nutrient requirements from pasture and a salt and mineral supplement. Hay is provided to the flock when forages are limited, and grain may be added to the diet at certain stages of production when additional nutrient supplementation is required. Small grain pastures or stockpiled fescue can supply up to one-half of the feed requirements of the ewe flock during the winter.

\begin{tabular}{|c|c|c|c|}
\hline \multirow{2}{*}{ Sheep Type } & \multirow{2}{*}{$\begin{array}{l}\text { Additional feeding } \\
\text { ingredients)) }\end{array}$} & In winter & In summer \\
\hline & & Head \day & Head \day \\
\hline & Sudanese sorghum & $150-200 \mathrm{gm}$ & $250-300 \mathrm{gm}$ \\
\hline & Cotton seed cake & $100-200 \mathrm{gm}$ & $200-250 \mathrm{gm}$ \\
\hline & Sorghum byproduct hay & Ad libitum & Ad libitum \\
\hline & Pasture hay (gabash) & Ad libitum & Ad libitum \\
\hline & Sudanese sorghum & $150-200 \mathrm{gm}$ & $250-300 \mathrm{gm}$ \\
\hline & Cotton seed cake & $100-200 \mathrm{gm}$ & $200-250 \mathrm{gm}$ \\
\hline & Groundnut byproduct hay & Ad libitum & Ad libitum \\
\hline & Sorghum byproduct hay & Ad libitum & Ad libitum \\
\hline & Pasture hay (gabash) & Ad libitum & Ad libitum \\
\hline & Sudanese sorghum & $150-200 \mathrm{gm}$ & $250-300 \mathrm{gm}$ \\
\hline & Cotton seed cake & $100-200 \mathrm{gm}$ & $200-250 \mathrm{gm}$ \\
\hline & Groundnut byproduct hay & Ad libitum & Ad libitum \\
\hline & Sorghum byproduct hay & Ad libitum & Ad libitum \\
\hline & Sudanese sorghum & $150-200 \mathrm{gm}$ & $250-300 \mathrm{gm}$ \\
\hline & Cotton seed cake & $100-200 \mathrm{gm}$ & $200-250 \mathrm{gm}$ \\
\hline & Groundnut byproduct hay & Ad libitum & Ad libitum \\
\hline & Sorghum byproduct hay & Ad libitum & Ad libitum \\
\hline & Sudanese sorghum & $150-200 \mathrm{gm}$ & $250-300 \mathrm{gm}$ \\
\hline & Cotton seed cake & $100-200 \mathrm{gm}$ & $200-250 \mathrm{gm}$ \\
\hline & Sorghum byproduct hay & Ad libitum & Ad libitum \\
\hline & Sesame byproduct hay & Ad libitum & Ad libitum \\
\hline
\end{tabular}

Table 2: Additional feeding stuff on summer and winter fed for Sudan desert sheep and their amounts.

Dominant plant species which are edible for sheep in both poor and enrich pastures in the study locations are presented in tables 3-7.

\begin{tabular}{|c|c|c|c|}
\hline \multicolumn{2}{|c|}{ Feed Grazed Plant in Good } & \multicolumn{2}{|c|}{ Grazed Plants in Poor Feed Condition Area } \\
\hline Local name & Scientific name & Local name & Scientific name \\
\hline Danab alnagga & Schoenfeldia gracils & Gao & Aristida $s s p$ \\
\hline Gao & Aristida ssp & Beno & Eragrostis tremula \\
\hline Beno & Eragrostis tremula & Haskaneet kheshin & Cenchrus biflorus \\
\hline Um selala & Aristida mutablis & Um selala & Aristida mutablis \\
\hline Abu asabie & Dactyloctenium aegyptium & Tamam & Panicum turgidum \\
\hline Tamam & Panicum turgidum & Argasi & Chrozophora brochianna \\
\hline Haskaneet naeim & Cenchrus ciliaris & & \\
\hline Um lebena & Euphoebia aegyptiaca & & \\
\hline Hanthal & Colocynthis vulgaris & & \\
\hline Dahayan & Farsetia londisclizua & & \\
\hline Defra & Echinocloa colonum & & \\
\hline Shraya & Indigofra semitrijuga & & \\
\hline
\end{tabular}

Table 3: Dominant pasture plants species on autumn in Kabashi Sudan desert sheep grazed areas. 


\section{Open Access Journal of Veterinary Science \& Research}

\begin{tabular}{|c|c|c|c|}
\hline \multicolumn{2}{|c|}{ Grazed plants in good feed condition area } & \multicolumn{2}{c|}{ Grazed plants in poor feed condition area } \\
\hline Local name & Scientific name & Local name & Scientific name \\
\hline Beno & Eragrostis tremula & Sheleni & Zornia diphylla \\
\hline Gao & Aristida ssp & Abu asabie & Dactyloctenium aegyptium \\
\hline Danab alnagga & Schoenfeldia gracils & Beno & Eragrostis tremula \\
\hline Lessag & Commicarpus africanus & Gao & Aristida ssp \\
\hline Haskaneet naeim & Cenchrus ciliaris & Humra & Aristida adscensionis \\
\hline Um fisasiyat & Fimbristyls dichotomo & Haskaneet kheshin & Cenchrus biflorus \\
\hline Tabar & Ipomeas cordoba & Cememma & Hyparrhenia hirta \\
\hline Tmr alfar & Acanthus ssp & Um fisasiyat & Fimbristyls dichotomo \\
\hline Cememma & Hyparrhenia hirta & Dahayan & Farsetia londisclizua \\
\hline argasi & Chrozophora brochianna & Simsim algumal & Sesamum alatum \\
\hline Simsim algumal & Sesamum alatum & Danab alnagga & Schoenfeldia gracils \\
\hline Khurata & Tephrosia bracteoluta & Batyhk alaj & Colocynthis citrullus \\
\hline & & Um lebena & Euphoebia aegyptiaca \\
\hline
\end{tabular}

Table 4: Dominant pasture plants species on autumn in Hamari Sudan desert sheep grazed areas.

\begin{tabular}{|c|c|c|c|}
\hline \multicolumn{2}{|c|}{ Grazed plants in poor feed condition area } & \multicolumn{2}{|c|}{ Grazed plants in good feed condition area } \\
\hline Local name & Scientific name & Local name & Scientific name \\
\hline Rebaa & Zalea pemtandra & Abu asabie & Dactyloctenium aegyptium \\
\hline Abu asabie & Dactyloctenium aegyptium & Tamam & Panicum turgidum \\
\hline Haskaneet naeim & Cenchrus ciliaris & Haskaneet kheshin & Cenchrus biflorus \\
\hline Addan alfar & Requenia obcordata & Gubain & Solanum dubium \\
\hline Beno & Eragrostis tremula & Beno & Eragrostis tremula \\
\hline Gao & Aristida ssp & Gao & Aristida ssp \\
\hline Um lebena & Euphoebia aegyptiaca & Dressa & \\
\hline Almahreeb & Cymbopogon marginatus & & \\
\hline Tagtaga & Pavonia patens & & \\
\hline Alnal & Cymbopogon nervatus & & \\
\hline Difra & Echinocloa colonum & & \\
\hline Dressa & Tribulis terrstris & & \\
\hline
\end{tabular}

Table 5: Dominant pasture plants species on autum in Shogor Sudan desert sheep grazed areas.

\begin{tabular}{|c|c|c|c|}
\hline \multicolumn{2}{|c|}{ Grazed plants in good feed condition area } & \multicolumn{2}{c|}{ Grazed plants in poor feed condition area } \\
\hline local name & Scientific name & local name & Scientific name \\
\hline Rebaa & Zalea pemtandra & Abu asabie & Dactyloctenium aegyptium \\
\hline Abu asabie & Dactyloctenium aegyptium & Tamam & Panicum turgidum \\
\hline Haskaneet naeim & Cenchrus ciliaris & Gubain & Solanum dubium \\
\hline Addan alfar & Requenia obcordata & Beno & Eragrostis tremula \\
\hline Beno & Eragrostis tremula & Gao & Aristida ssp \\
\hline Gao & Aristida ssp & Haskaneet kheshin & \\
\hline Um lebena & Euphoebia aegyptiaca & & \\
\hline Tagtaga & Pavonia patens & & \\
\hline Alnal & Cymbopogon nervatus & & \\
\hline Difra & Echinocloa colonum & & \\
\hline
\end{tabular}

Table 6: Dominant pasture plants species on autumn in Dubasi Sudan desert sheep grazed areas. 


\section{Open Access Journal of Veterinary Science \& Research}

\begin{tabular}{|c|c|c|c|}
\hline \multicolumn{2}{|c|}{ Grazed plants in good feed condition area } & \multicolumn{2}{|c|}{ Grazed plants in poor feed condition area } \\
\hline Local name & Scientific name & Local name & Scientific name \\
\hline Tabar & Ipomeas cordoba & Gubain & Solanum dubium \\
\hline Hantoot & Ipomea sinensis & Beno & Eragrostis tremula \\
\hline Rehan & Geigeria alata & Gao & Aristida ssp \\
\hline Mulaita & Launaea capitata & Haskaneet kheshin & Cenchrus biflorus \\
\hline Beno & Eragrostis tremula & Abu asabie & Dactyloctenium aegyptium \\
\hline Gao & Aristida ssp & \multicolumn{2}{|}{} \\
\hline Abu asabie & Dactyloctenium aegyptium & \multicolumn{2}{|}{} \\
\hline Haskaneet naeim & Cenchrus ciliaris & \multicolumn{2}{|c|}{} \\
\hline
\end{tabular}

Table 7: Dominant pasture plants species on autumn in Watish Sudan desert sheep grazed areas.

Most of sheep skins obtained from these animals were manually flayed. Ripping flaying method on the ground is commonly used for cattle flaying. On the other hand fist method on hoist is commonly used for goats and sheep skinning. Generally two edge knives are always used in flaying sheep skins. Common flaying defects were resulting mostly from scars (67\%) in sheep skins with different degrees, followed by cuts $(12 \%)$ in sheep skins and lastly flaying holes. This is agreeing with Said, et al. [8] who determined damages during slaughtering and skinning with $20-30 \%$ of the total damages.

Branding is the most common and known damage in skins generally. Ear trimming is the common branding method is often used for sheep as a mean of proving ownership for farm animals especially Sudan desert sheep. Also some animal breeder's belief that by means of hot iron branding some animals may acquire immunity against certain diseases. For this purpose hot iron branding mostly applied over ribs skin in both sides of animal as a treatment for respiratory diseases. Hot iron branding methods were usually made in the best part of a skin and hence destroy the finished leather of that part. This is in line with Ibrahim [9] who reported that branding methods were usually made in the best part of a skin and hence destroy the finished leather of that part. Aten, et al. [10] also observed that form of branding was used by cattle owners for curing disease.

Respondents return most of mechanical damages on skins to spinal bushes. They also think that these damages are somewhat fewer in skins of sheep and goats relatively to cattle hides. There are some other factors cause skins damages with different degrees such as housing fences, grass seeds and scratches. Also horn marks are other sources for mechanical damages especially in horned male animals. Horn marks on animals are often noticed on abdomen, followed by four quarters and lastly hind quarters. All sheep breeders used dehorning technique when needed. Those findings agree with that reported by
Aten, et al. [10] who stated that, scratches are a very common type of damage caused by thorns, barbed wire and horns. Damages due to horns are usually in the abdomen, forequarters or hindquarters.

Dependence on natural pasture under open grazing systems for animal feeding caused the most common and known scratch damages on sheep skins. The respondents attributed causes of damages of skins of animals on range land mainly to the domination of thorny bushes and grass with hairy and spiny seeds in pastures. Thus, the high percentage of damages of skins obtained from nomadic livestock in Sudan desert sheep area hence could be explained on the ground that those animals move long distances and graze during that time thorny bushes and grasses and are subjected to fighting when on range land using horns (Table 8).

\begin{tabular}{|c|c|}
\hline Flaying Defects & $\mathbf{\%}$ \\
\hline Holes & 12 \\
\hline Cuts & 21 \\
\hline Scars & 67 \\
\hline Common Branding & $\mathbf{\%}$ \\
\hline Hot iron & 14 \\
\hline ear tags & 4 \\
\hline ear trimming & 82 \\
\hline Other & 0 \\
\hline Scratch Marks Causes & $\mathbf{\%}$ \\
\hline Spinal bushes & 90 \\
\hline Fences & 6 \\
\hline Others & 4 \\
\hline
\end{tabular}

Table 8: Common types of flaying, branding and scratch marks causes on Sudan desert sheep skins.

External parasites and skin diseases cause most of skins damages and wastages in Sudan generally. Sheep pox spreads on sheep skins with high rates (88\%). On the other hand, mange are resulting in (8\%) of sheep skins infections. However, ticks infect most of sheep skins 


\section{Open Access Journal of Veterinary Science \& Research}

(80\%), when Lice infection estimated at $20 \%$ of sheep skins. This confirms the results reported by Abusamra [11] that over $50 \%$ of sheep were found to be infested with ticks. In spite of the high infestation of ticks, their effects on hides and skins' quality were minimal. Abusamra, [11] argued that, most of ticks' sores were located in areas which would either be peripheral or were trimmed off during fleshing process (Table 9).

\begin{tabular}{|c|c|}
\hline Common Skin Diseases & $\mathbf{\%}$ \\
\hline Ring worm & 0 \\
\hline Mange & 8 \\
\hline Pox & 88 \\
\hline Other & 8 \\
\hline Common External Parasites & $\mathbf{\%}$ \\
\hline Ticks & 80 \\
\hline Mites & 0 \\
\hline Lice & 20 \\
\hline
\end{tabular}

Table 9: Sudan desert sheep common skin diseases and external parasites.

The majority of the respondents preserved flayed skins directly without preparation processes; where fewer of them fleshed it when received. Putrefaction occurred in most prepared hides and skins before preservation as a result of poor preservation applied. The larger part of prepared sheep skins (92\%) were mostly preserved with salt adding technique. On the other hand air drying was used to a lesser degree (8\%) on sheep skins curing. Technically most of sheep skins were dried on the ground; where only $8 \%$ of sheep skins were dried using the robe suspension drying technique. Preserved sheep skins were generally stored on the ground. These confirm Devassy and Argaw (1989) and Elliott (1981) $[12,13]$ mentioned that, drying on the ground is the most traditional and simplest of curing techniques and at the same time the more undesirable. Hides and skins are put on the ground with flesh side up and allowed to dry. Pegs or stones are used at the edges to keep the hide or skin flat out.

The majority of sheep skins (72\%) were evaluated depending on defects and size; where $12 \%$ of sheep skins were evaluated depending on defects. Similarly, few sheep skins were evaluated depending on size (Table 10).

\begin{tabular}{|c|c|}
\hline Preservation Methods & $\mathbf{\%}$ \\
\hline Air-drying & 8 \\
\hline Pickled & 0 \\
\hline Dry-salting & 92 \\
\hline Drying methods application & $\mathbf{\%}$ \\
\hline Frames & 0 \\
\hline
\end{tabular}

\begin{tabular}{|c|c|}
\hline Robe suspension & 8 \\
\hline On the ground & 92 \\
\hline Storage ways & $\mathbf{\%}$ \\
\hline On floor & 100 \\
\hline On plat form & 0 \\
\hline Evaluation methods & $\%$ \\
\hline On defects & 18 \\
\hline On weight & 0 \\
\hline On size & 12 \\
\hline Defects\& size & 72 \\
\hline
\end{tabular}

Table 10: Preservation methods, application, storage ways, Evaluation and pricing methods for sheep skins.

\section{Conclusion}

Sudan desert sheep production is a very complex system which has many interrelated components such as climate, soil, plants and obviously, animals operating with a high degree of interaction within a certain economic and social environment.

\section{References}

1. Al-Nahar (2011) Importance of livestock- number 356. Kuwaiti newspaper.

2. Alraed electronic newspaper (2011) Forage gap: threatening livestock.

3. El-Hag FM, Fadlalla B, Elmadih MA (2001) Effect of strategic supplementary feeding on ewe productivity under range conditions in North Kordofan, Sudan. Small Ruminant Research 30(1): 67-71.

4. Farah, Sheikh Eldin (2006) Proposed research projects, a multidisciplinary approach in natural resources management for food security, poverty alleviation and sustainable development in Kordofan states in western Sudan. University of Kordofan, Elobied, Sudan.

5. Wikipedia, the free encyclopedia (2014) Al Jazirah (state).

6. Darosa AEM, Agab H (2013) Studies on some camel (Camelus dromedarius) production traits, health and constraints in Butana area, Sudan. J of Camel Practice \& Res, pp: 1-21.

7. Mufarrih ME (1991) Sudan desert sheep: Their origin, ecology and production potential. Ministry of Animal Resources, Sudan. 
8. Said Abelateef Mohamed, Abdelmajed Mustafa Alfakki, Mohamed Abdelgadir Aornanassir (1999) Leathr Production economics (Study) Ministry of Animal Wealth and Fisheries. Khartoum, Sudan.

9. Ibrahim KE (1983) Investigations on the defects caused by physical damage, streptothricosis and mange on crust leather and their economic significance in leather industry. B.V.Sc. thesis, University of Khartoum, Sudan.

10. Aten A, Faraday Innes R, Knew E (1985) Flaying and curing of hides and skins as a rural industry. FAO
(Food and Agriculture Organization of the United Nations), Rome, Italy.

11. Abusamra MT (1974) Some skin diseases of domestic animals in the Sudan: with especial References to Cutaneou Streptothericosis. M.V.Sc. thesis, University of Khartoum, Sudan.

12. Devassy TJ, Argaw Getachew (1989) Hides and Skins Improvement. Hand book, Addis Ababa, Ethiopia.

13. Elliott RGH (1985) Hides and skins improvement in developing countries. FAO Agriculture service bulletin. 